Conceiving of Personality 
This page intentionally left blank 
Yale University Press New Haven and London

\section{Conceiving of Personality}

Michael Robbins, M.D. 
Copyright (C) 1996 by Michael Robbins. All rights reserved. This book may not be reproduced, in whole or in part, including illustrations, in any form (beyond that copying permitted by Sections 107 and 108 of the U.S. Copyright Law and except by reviewers for the public press), without written permission from the publishers.

Designed by Rebecca Gibb.

Set in Joanna type by The Composing Room of Michigan, Inc., Grand Rapids, Michigan.

Printed in the United States of America by Vail-Ballou Press. Binghamton, New York.

\section{Library of Congress Cataloging-in-Publication Data}

Robbins, Michael, M.D.

Conceiving of personality / Michael Robbins.

p. $\mathrm{cm}$.

Includes bibliographical references and index.

ISBN 0-300-06422-5 (alk. paper)

1. Personality. 2. Psychoanalysis. 3. Ethnopsychology.

4. Psychology and philosophy. I. Title.

BF698.R854 1996

$155.2-\mathrm{dc} 20$

$95-47043$

CIP

A catalogue record for this book is available from the

British Library.

The paper in this book meets the guidelines for permanence and durability of the Committee on Production Guidelines for Book Longevity of the Council on Library Resources. 
To the personalities in my life-conceivable and inconceivablewho presented the challenge that stimulated me to write this book. And particularly to Barbara and to Seb for the support that enabled me to complete it. 
This page intentionally left blank 